\title{
Stimulating renewable energy technologies by innovation policy
}

\author{
Simona O Negro, Marko P Hekkert and Ruud E H M Smits
}

\begin{abstract}
In this paper we analyse the dynamics of three emerging innovation systems by using the system functions approach in which the underlying key activities that contribute to the build up of an innovation system are identified. The insights gained with respect to the dynamic functional patterns specific for each emerging innovation system will allow us to identify system failures and develop policy and policy measures that start out from an innovation systems' perspective. We will present initial ideas on the building blocks for a more systemic policy aiming to support the development of new emerging innovation systems (and in doing so break down parts of the old innovation systems).
\end{abstract}

I NNOVATION IS BECOMING increasingly important for Western countries. The rise of China and India, nations that are rapidly developing their scientific and technological base and becoming worthy competitors in international markets, plus the need to solve urgent societal problems such as climate change, urge countries to improve their innovative capacities. Nevertheless, innovation is a complex process. Despite this, for many years a rather simplistic model of innovation processes has dominated the scene. This model became known as the linear model of innovation and was very well characterised by the slogan of the 1934 World Expo in Chicago: 'Science finds, Industry applies, Man conforms'. Failures in the market and new insights obtained from innovation theory deepened our understanding of innovation processes. Scholars such as Nelson and Winter (1977), Rip (1978), Bijker et al (1987), Etzkowitz and Leydesdorff (2000) and Ziman (2001) emphasise that innovation based on science is the result of social and economic

Simona O Negro is at the Innovation Studies Group, Copernicus Institute for Sustainable Development and Innovation, Faculty of Geo-sciences, Utrecht University, Heidelberglaan 2, 3584 CS Utrecht, The Netherlands; Email: s.negro@geo.uu.nl; Tel: + 3130253 7166; Fax: + 3130253 2746. All the authors are affiliated to the Department of Innovation Studies, Copernicus Institute for Innovation and Sustainable Development at Utrecht University in the Netherlands. processes, and thus - almost by definition - is not a deterministic process.

Today, innovation is no longer seen as an autonomous process dominated by scientists and industrialists, but as part of a 'game' in which a heterogeneous set of actors is involved (Dosi et al, 1988; Smits and Kuhlmann, 2004). Innovation is seen from an economic and/or societal point of view as the successful combination of hardware, software and orgware. Orgware here refers to the context in which innovations take place. The basic idea behind this definition is that we may only speak of an innovation if it is successful in economic and/or societal terms.

Nowadays the point of departure taken by innovation scholars is that organisations are not innovating in isolation but in the context of a system (Freeman and Lundvall, 1988; Lundvall, 1992; Nelson, 1993). As a consequence their performance is dependent on the quality of that system, especially on the quality of the subsystems (R\&D, users, intermediary and supportive infrastructure), and on the mutual tuning of these subsystems (Freeman, 1997; Smits, 2002). This system became known as the innovation system'. Freeman (1987: p.1) defined an innovation system as 'The network of institutions in the public and private sector whose activities and interconnections initiate, import and diffuse new technologies'. An important consequence of the systems approach is that not only scientists and firms but also a far broader and more heterogeneous set of actors, often 
Dr Simona O Negro is an assistant professor. She wrote her $\mathrm{PhD}$ thesis (2007) on 'Dynamics of Technological Innovation Systems - the Case of Biomass Energy' and is now conducting research on eco-innovation and the transition to a sustainable energy system.

Professor Dr Marko P Hekkert is a full professor of innovation system dynamics, much of his research time being devoted to studying the process of sustainable technological change and eco-innovation.

Professor Dr Ruud E H M Smits is a full time professor of technology and innovation, the focus of his work being on the development of more user-oriented types of innovation policy and management, technology assessment and on the dynamics of innovation systems (transitions, systemic instruments, relation between processes and systems).

operating at different levels and in various arenas, are involved in (the management of) innovation processes (Kuhlmann et al, 1999). Actors, relations and institutions (the rules of the game) constitute the (static) structure of innovation systems. Crucial functions, supported by the aforementioned structural elements, determine the dynamics of the IS.

Recent insights within the innovation system approach show that for an innovation to be successful a chain of positive feedback loops between several components and activities within the innovation system need to occur (Jacobsson and Bergek, 2004; Negro, 2007; Negro et al, 2007, 2008). These interactions might be circular and set a process of cumulative causation into motion. In the case of an emerging technology this process will lead to the build-up of an innovation system around that technology.

In recent years several scholars have studied these processes of cumulative causation by focusing on the interaction between the key activities that need to take place in the innovation system. These key activities are often labelled as functions of innovation systems (Edquist, 1997; Johnson, 1998). Insights into how an emerging innovation system is functioning obtained from studying these key activities and their interactions could be an excellent basis for government intervention and policy-making that aims to contribute to well-functioning innovation systems and thereby accelerating innovation processes.

The main questions addressed in this paper are whether, why and how government was able to stimulate innovation in three renewable energy technologies: biomass combustion, gasification and cofiring in the Netherlands over the period from 1990 to 2004. The 'whether question' relates to the legitimisation of governmental policies. Government is only allowed to intervene if:

1. A societal goal is at stake;

2. Other actors are unable to reach this goal; and

3. Government is able to intervene both effectively and efficiently.
When speaking of innovation in terms of renewable energy technologies, it is clear that we are dealing with a societal problem (sustainable development). The necessity to substitute fossil fuels by renewable energy options is widely known and accepted; however, the diffusion of such technologies is slow and tedious. The questions as to which part of the necessary actions government is responsible for, and whether government is capable of stimulating and implementing these actions, are not so easy to answer. In this paper we will analyse innovation processes of three renewable energy technologies in order to answer these two questions. In doing so we will also address the 'why' question. We will focus on two important and generally accepted roles of government:

1. Responsibility for a high-level infrastructure to facilitate innovation; and

2. Ownership of societal problems, in this case: the need to stimulate renewable energy.

The focus of this paper can be summarised as the following research questions:

- What are the differences in innovation system dynamics for three renewable energy technologies in the Netherlands?

- Which policy and policy instruments should the government develop when starting from an 'innovation systems' perspective?

An overview of the innovation systems approach and system functions concept is given in the first section of this paper. Then the three technology trajectories are described and innovation system dynamics are analysed. The conclusion sets out the lessons learned and the policy implications involved.

\section{Innovation systems, system functions and policy}

In the literature, different types of innovation systems are discerned, each focusing on a specific aspect depending on the unit of analysis used. The national innovation systems approach uses the country as the unit of analysis, influencing the technology choice and learning processes (Freeman, 1987; Lundvall, 1992; Nelson, 1992). We then have the regional innovation systems approach within a country, in which the cultural variables, such as social networks, are important (Saxenian, 1991). The sectoral innovation system focuses on the firms that are engaged in the innovative activities of a sector (Breschi and Malerba, 1997). All of these approaches mainly focus on the analysis of structural elements of the respective innovation systems.

The structural elements are useful for delineating the system; however, they differ strongly per country or per technology. In addition, if only the 
The concept of technological innovation systems focuses only on those structural elements (institutions, actors, and networks) that directly influence the development and diffusion of a specific technology

structures of different systems are compared, and the differences in performance are explained with respect to the differences in structure, then less attention is paid to the dynamics of innovation systems. This makes the analysis of an Innovation system quite static. Since the interest of our research lies in creating insight into the dynamics of the development and diffusion of renewable energy, another approach is needed that allows a dynamic analysis of the innovation system.

In this case, the technological innovation systems (TIS) approach is the most suitable one since it focuses on a particular technology and includes factors that are specific to the technology studied (Carlsson and Stankiewicz, 1991; Carlsson, 1997). The concept of TIS focuses only on those structural elements (institutions, actors, and networks) that directly influence the development and diffusion of a specific technology. This is a useful delineation if the focus is to identify the characteristics of the specific system associated with an emerging technology, its strengths and weaknesses, as well as its dynamics (Jacobsson and Johnson, 2000). Since Carlsson and Stankiewicz (1991) introduced these concepts they have been developed into an approach that focuses on the understanding of system dynamics. The TIS is defined by Carlsson and Stankiewicz (1991: 94) as 'a network or networks of agents interacting in a specific technology area under a particular institutional infrastructure to generate, diffuse, and utilise technology.' This implies that there is a TIS for all technologies and that each TIS is unique in its ability to develop and diffuse a new technology (Jacobsson and Johnson, 2000).

When the TIS is in the early stages of emergence the number of actors, networks, and relevant institutions is small, which reduces the complexity. This makes it possible to map the dynamics of an emerging TIS. This can be done by identifying the key activities that take place within the TIS that influence the development, diffusion, and use of an innovation (Edquist, 2001, 2004). These activities are also called 'functions of innovation systems' ('system functions') (Johnson, 1998). Jacobsson and Johnson (2000) developed the concept so that a system function is defined as 'a contribution of a component or a set of components to a system's performance' (Bergek, 2002: 21). They state that a TIS may be described and analysed in terms of its 'functional pattern', i.e. how these functions have been served (Johnson and Jacobsson, 2002: 3). The system functions are related to the character of and the interaction between the components of an innovation system, i.e. actors (e.g. firms and other organisations), networks, and institutions, either specific to one TIS or 'shared' between a number of different systems (Edquist, 2001). In this paper the recently developed list of system functions is applied (Suurs and Hekkert, 2005, submitted; Hekkert et al, 2007; Negro 2007; Negro et al, 2007, 2008). This list of system functions has to a large extent been developed in agreement with colleagues from Chalmers University (Sweden), to be applied to empirical work both in the Utrecht and the Chalmers group.

\section{Function 1: entrepreneurial activities}

The existence of entrepreneurs in innovation systems is of prime importance. Without entrepreneurs no innovation would take place and the innovation system would not even exist. The role of the entrepreneur is to turn the potential of new knowledge development, networks and markets into concrete action to generate and take advantage of business opportunities.

\section{Function 2: knowledge development (learning)}

Mechanisms of learning are at the heart of any innovation process. For instance, according to Lundvall: 'the most fundamental resource in the modern economy is knowledge and, accordingly, the most important process is learning' (Lundvall, 1992). Therefore, R\&D and knowledge development are prerequisites within the innovation system. This function encompasses 'learning by searching' and 'learning by doing'.

\section{Function 3: knowledge diffusion through networks}

The essential characteristic of networks is to exchange information, such as fundamental knowledge or knowledge about how to use a technology.

\section{Function 4: guidance of the search}

The activities within the innovation system that can positively affect the visibility and clarity of specific needs among technology users fall under system function: guidance of the search. A relevant example of this is a government's announcement of its goal to aim for a certain percentage of renewable energy in a future year. This event gives a certain degree of legitimacy to the development of sustainable energy technologies and stimulates the allocation of resources for this particular development. Expectations are also included since expectations can 
occasionally converge on a specific topic and generate momentum for change in a specific direction.

\section{Function 5: market formation}

New technologies often have difficulty in competing with embedded technologies, therefore it is important to create protected spaces for new technologies. One possibility is the formation of temporary niche markets for specific applications of the technology (Schot, Hoogma et al., 1994). Another option is to create a temporary competitive advantage by introducing favourable tax regimes or minimal consumption quotas.

\section{Function 6: resource mobilisation}

Resources in terms of both finance and human capital are necessary as the basic input to all activities within the innovation system. And specifically for biomass technologies, the abundant availability of the biomass resource itself is also an underlying factor that determines the success or failure of a project.

\section{Function 7: advocacy coalition (creation of legitimacy/counteract resistance of change)}

In order for a new technology to develop well it must become part of an incumbent regime, or even overthrow it. Parties with vested interests will often oppose this force of 'creative destruction'. In such an event, advocacy coalitions can function as a catalyst; they put a new technology on the agenda (function guidance of the search), lobby for resources (function resource mobilisation), favourable tax regimes (function market formation) and by doing so create legitimacy for a new 'technological trajectory' (Sabatier, 1988, 1998; Sabatier and Jenkinssmith, 1988). If successful, advocacy coalitions grow in terms of size and influence and may become powerful enough to brisk up the spirit of creative destruction.

It is important that each individual system function is fulfilled. However, the growth of a TIS is claimed to be related to the interaction dynamics between the system functions. Positive interactions between system functions might turn out to be circular, setting in motion a process of cumulative causation (Jacobsson and Bergek, 2004). These virtuous cycles might then accelerate the growth of an innovation system and lead to the diffusion of a new technology.

Since the 1990s (Lundvall, 1992; Nelson, 1993) the concept of innovation systems has received enormous attention in the academic world, among policy-makers and in management circles (Borrás, 2004; Edquist, 2004). However, conceptual diffuseness dominates the innovation systems approach and more systematic work is needed to identify the determinants of innovations (Edquist, 2004).
Contributions to making the innovation systems approach more theory-like comprises comparative case studies, comparing innovation systems of various kinds, including the determinants (and consequences) of innovation processes within them (Edquist, 2004). In this paper we compare three technological innovation systems by carrying out longitudinal event analysis in order to identify the activities that occur in each TIS and thus identify the 'determinants' of innovation. The identification of such determinants or the lack of them is very important for policy purposes (Edquist, 2004).

When functional patterns are insufficient to sustain innovation system growth and technological progress, it is important that the causes are identified. In many cases these causes can be found in the innovation system structure. Either the necessary components are not in place, or the components fail to function the way they are supposed to do, or the components do not interact in a fruitful way. These types of problems in the structure of the innovation system are labelled as system failures (Klein Woolthuis et al, 2005).

The next question then is about the policies and instruments that may be effective and efficient to remove system failures. Based on a comparative analysis of innovation policy instruments portfolios from different countries (O'Doherty and Arnold, 2001; Joerg and Larrue, 2004; Arnold, 2007) and recent insights from innovation studies, Smits and Kuhlmann (2004) conclude that the present instrument portfolios are based on the linear model and are comprised of financial instruments (R\&D subsidies and tax-incentives) and instruments that focus on one organisation (management advice) or the link between two organisations (technology transfer, diffusion of technology). They further conclude that these portfolios should be complemented with instruments that take into account the systemic character of innovation processes. In particular they make a plea for instruments that focus on the following structural elements of innovation systems:

1. The capacity to manage interfaces,

2. The capacity to orchestrate at system level (alignment, the building of new structures, the breaking down of obsolete ones),

3. An infrastructure for strategic intelligence providing the various actors with the information they need to develop and implement their visions and ideas,

4. Platforms for learning and experimenting, and

5. The capacity to articulate demand and visions.

Smits and Kuhlman (2004) label instruments focusing on these structural elements as 'systemic instruments'. Systemic instruments can be defined as instruments that aim to improve the performance of a subset of an innovation system in a coordinated way. In its role as the party responsible for an infrastructure that stimulates innovation, the major task 
Systemic instruments can be defined as instruments that aim to improve the performance of a subset of an innovation system in a coordinated way

of government then is to identify major conditions and system failures and to decide which set of traditional and systemic instruments is most effective and efficient to create or remove the system failures and provide the right conditions.

To summarise, in order to identify which conditions are necessary and to find out whether or not any system failures are present, an analysis must be carried out and a comparison made between the structure and the dynamics of several innovation systems (Edquist, 2004). The analysis of a TIS, comprising the structural elements, functions, virtuous and vicious cycles and related conditions, constitute the necessary basis for effective and efficient innovation policy. In the following section such an analysis will be carried out for three biomass TIS that are at different stages of development.

\section{The case of biomass combustion, gasification and co-firing in the Netherlands from 1990 to 2004}

\section{Technological background}

Co-firing is a method of combining fossil and bioenergy fuels in conventional power plants. The typical size of power plants where co-firing is applied is between 50 MWe and 700 MWe (Loo and Koppejan, 2002). The amount of coal replaced by biomass can be considered as renewable energy (ECN Report, Ree, 2000).

In contrast to combining two fuel stocks in a conventional plant, stand-alone biomass combustion is a traditional way to convert biomass alone into electricity, where in most cases a new plant needs to be built. In such a case all the electricity produced is labelled as renewable energy.

An innovative and more efficient method is gasification of biomass. Using this method biomass is combusted in an oxygen-starved environment, the end products being $\mathrm{CO}$ and $\mathrm{H}_{2}$ gases (so-called producer gas or syn(thesis) gas). The gas produced is then fed into a gas turbine, which has a much higher efficiency (35-40\%) than the steam turbine used for combustion (25-30\%) (Williams and Larson, 1996; Faaij et al, 1997; Morris et al, 2005). In this paper we will focus on stand-alone biomass gasification.
Since the oil crises in the 1970s awareness of the finite amount of fossil fuels has increased and the Dutch Government published two energy white papers (1974 and 1979) to stimulate energy saving (function guidance of the search) (TweedeKamer, 1974, 1979). As the oil prices dropped in the 1980s, the energy-saving issue disappeared temporarily from the political agenda (lack of function guidance of the search). In the late 1980s, however, the aspect of environmental awareness was raised again after the publication of a highly influential report, which showed that in 10 years' time 17 million tonnes of $\mathrm{CO}_{2}$ could be reduced, and that there would be lower emissions of $\mathrm{SO}_{2}$ and $\mathrm{NO}_{\mathrm{x}}$ (EnergieNed, 2000).

This triggered the government to publish the first National Environmental Plan (NMP) and shortly after that the White Paper on Energy Saving (function guidance of the search). In these plans all participants of the Dutch economy were addressed regarding their own responsibility to help save energy in the Netherlands. The energy companies were given the main responsibility for reducing their customers' energy consumption (VROM, 1989). This inspired the energy companies to publish the first Environmental Action Plan (MAP-I) in 1991 and take the social responsibility for making a substantial contribution to a sustainable and environmentfriendly energy supply (function guidance of the search) (ECN, 1994; EnergieNed, 2000). In MAP-I measures were elaborated to achieve a reduction in $\mathrm{CO}_{2}$ emission of 9 million tonnes in 2000, i.e. a $10 \%$ reduction (EnergieNed, 2000).

These goals towards more sustainable development were taken over and sharpened up by the government in the second National Environmental Plan (NMP-Plus) and a second White Paper on Energy Saving (function guidance of the search) (EZ, 1993). As a result, after three years the $\mathrm{CO} 2$ reduction goals were doubled to 17 million tonnes in the third Environmental Action Plan (MAP-III) (EnergieNed, 2000). The reasons for the alteration were continuous economic growth and the resulting increase in energy consumption; research commissioned by the energy sector demonstrated the feasibility of the energy companies reducing that amount of carbon dioxide (function knowledge development) (EnergieNed, 2000). Thus in this period, strong guidance by the government was the key driver that led to actions to reduce $\mathrm{CO}_{2}$ emissions (function guidance of the search).

Alongside the need to reduce $\mathrm{CO}_{2}$ emissions and produce renewable energy, the Netherlands struggled with the problem of waste and agricultural surplus. Research led to the recognition that combustion technology was a promising option to reduce waste and agricultural surplus, plus the additional benefit of producing energy (function knowledge development) (NE\&S, 1981, 1982, 1983; Davids, 
1984; Novem, 1984). To prevent any increase of emissions the Ministry of Housing, Spatial Planning and the Environment (Ministry of the Environment; VROM) introduced several emission regulations (BEES A, Directive for Combustion) to limit the amount of air pollution which was expected to increase as more waste would be combusted (function guidance of the search) (VROM, 1987; EnergieConsulent, 1992b). In addition, several research programmes were set up: on the national level, such as the EWAB, NOH and Ten Years Waste Programme, and on the European level, such as the Thermie and Joule Programme, to increase the level of knowledge and guide the generation of energy from waste and biomass (function knowledge development, function guidance of the search) (DE, 1989, 1990; EU, 1990; TweedeKamer, 1990; E\&MSpectrum, 1992). The knowledge obtained in these research programmes led researchers to continue their research in order to reduce emissions, improve the efficiency of energy production, find appropriate biomass streams and efficient conversion technologies (function knowledge development) (DE, 1991a,b, 1992c; EnergieConsulent, 1992a).

Nevertheless, the results obtained all differed and represented the divisions within the energy sector and the competition between the available technologies. On the one hand, waste wood, demolition wood and thinnings played an important role in the EWAB programme for small-scale stand-alone biomass combustion plants (function guidance of the search) (DE, 1992a,d). On the other hand, the director of the United Electricity Producers (SEP), Mr Ketting, saw the use of large-scale electricity plants as a solution to the waste problem. When co-firing waste wood a certain percentage of coal is replaced, thus reducing emissions, and the wood waste is usefully processed (function guidance of the search) (EnergieConsulent, 1992; DE, 1992b). Then again, the research side gave preference to biomass gasification, labelled as a superior technology thanks to its higher energy conversion efficiency and flexible output (such as electricity or syngas that can be used for several different applications) (DE, 1992c,e).

These different results led to several technological trajectories being developed in the following years. Below is an overview of the individual trajectories of co-firing, biomass gasification, and biomass combustion to illustrate the development and diffusion of these technologies.

\section{Co-firing of biomass in coal plants}

The first co-firing experiments started in the early 1990s (function entrepreneurial activity). The driver was the agreement between the energy companies and the government in the MAP to reduce 17 million tonnes of $\mathrm{CO}_{2}$ emissions by 2000 (function guidance of the search) (DE, 1990; TweedeKamer, 1990; E\&MSpectrum, 1992; EnergieConsulent, 1992a). The experiments turned out to be successful and promising (function knowledge development) and showed that technical problems were indeed solvable (function guidance of the search). As a result, the Dutch energy companies applied for permanent co-firing permits in the mid-1990s (function entrepreneurial activity) (DE, 1995). By 2000 most of the Dutch coal plants were permanently co-firing up to $5 \%$ biomass in their plants (function market formation) (DE, 1996, 1997; Raven, 2005). Financial resources were provided by budgets reserved within the MAP agreement, and biomass availability was ensured by local, national collection or import (function resource mobilisation). However, over the years lengthy permit procedures delayed several projects, and neighbouring residents or environmental organisations opposed the co-firing of biomass with protests (lack of function advocacy coalition) (Stromen 2001a,b,c). Additionally, contradictory emission rules and the lack of categorisation of biomass and waste also resulted in delay and high project costs (lack of function guidance of the search) (DE, 1998; Stromen, 2001d).

The two existing ministerial orders (BLA and BEES-A) dictated the emission standards for waste incinerators and energy plants respectively, whereas a third standard (NER) prescribed emission standards for all other cases (Stromen, 2001d; Raven, 2005). However, there was still confusion when the waste, which was subject to the BLA standard, was combusted in plants that were subject to the BEESA standard (Stromen 2001d).

Finally, after several years of lobbying by the Dutch energy companies (function advocacy coalition), the Ministry of the Environment presented an emission framework (function guidance of the search) that was based on a distinction between clean ('the white list') and polluted ('the yellow list') organic material and could be applied independently of the type of plant (see Table 1 for an overview of emission standards) (Stromen, 2000a,b; 2001d). This emission framework was attached to the 2002 'Coal Covenant' (function market formation) (ECN, 2002). The coal covenant was introduced given that the emissions of $\mathrm{CO}_{2}$ needed to be reduced even further (Stromen, 2000a). A new target was set to reduce a further 5.8 million tonnes of $\mathrm{CO}_{2}$ over the period 2008-2012. To realise this target the production companies could either switch from coal to natural gas, close down a coal plant or co-fire biomass, i.e. in which the coal share had to be replaced with about $20 \%$ in the short term and in mid term by some $40 \%$ biomass resulting in a co-firing capacity of 475 MWe (ECN, 2002; IPO, 2003). In exchange for the latter option the government promised not to implement new regulations for the emission of polluting substances $\left(\mathrm{Hg}, \mathrm{NO}_{\mathrm{x}}\right.$ and $\mathrm{SO}_{2}$ ) since the levels were already lower than dictated by European regulations (ECN, 2002).

The introduction of the coal covenant shows that governmental guidance had two effects. On the one hand this guidance exerted a great deal of pressure 


\begin{tabular}{|c|c|c|}
\hline Year & Emission rules & Content \\
\hline 1992 & $\begin{array}{l}\text { BEES-A: Order for emission standards for } \\
\text { boilers }^{1}\end{array}$ & $\begin{array}{l}\text { Order that dictates emission standards for energy generation; limits for } \mathrm{NO}_{\mathrm{x}} \text {, } \\
\mathrm{SO}_{2} \text { and dust }\end{array}$ \\
\hline 1993 & $\begin{array}{l}\text { BLA: Order for emissions to air from waste } \\
\text { combustion }^{2}\end{array}$ & $\begin{array}{l}\text { Order that dictates emission standards for waste combustion; limits for mercury, } \\
\text { heavy metals and dioxins }\end{array}$ \\
\hline 1998 & NER-standard ${ }^{3}$ & Order that dictates emission standards for any other case \\
\hline 2002 & Coal covenant & $\begin{array}{l}\text { Framework based on a distinction between clean organic material, 'white list' } \\
\text { and polluted organic material, 'yellow list'. The combustion of materials on the } \\
\text { yellow list is subject to emission limits for } \mathrm{NO}_{x}, \mathrm{SO}_{2} \text { and dust. Combustion of } \\
\text { materials on the yellow list is also subject to limits for other toxins }\end{array}$ \\
\hline
\end{tabular}

Notes: $\quad$ 1. In Dutch: Besluit emissie-eisen stookinstallaties milieubeheer A

2. In Dutch: Besluit luchtemissies afvalverbranding

3. In Dutch: Nederlandse Emissie Richtlijn

on the coal plants to reduce their $\mathrm{CO}_{2}$ emissions. On the other hand, it did provide favourable conditions for biomass co-firing, since it forced energy companies to come up with alternatives that fulfilled the goals of the covenant (function guidance of the search). Thus a niche market was quickly created for biomass co-firing given that most of the coal plants implemented this option within a short period of time (function market formation) (see Table 2 for an overview of the co-firing activities) (ECN, 2002; Jünginger and Faaij, 2005; Raven, 2005).

In summary, the fast development of co-firing from a small niche into one of the largest renewable energy niches over a short period of time (i.e. 10 years) resulted from the favourable technical aspects (reliable, cheap and low risk), and that a market was formed (function market formation) for biomass cofiring (function market formation). The trigger was the urgency of the government to reduce $\mathrm{CO}_{2}$, which led energy companies to agree voluntarily (MAP) to contribute to $\mathrm{CO}_{2}$ emission reduction by developing several options, including co-firing (function entrepreneurial activity). Since most of the technical problems had been solved, co-firing was quickly introduced on a permanent basis in coal plants. In addition, since the plants already existed and the infrastructure was available, the costs remained low. In this case it was unnecessary for the technological innovation system to be built up from scratch because most of the required elements, such as actors, institutions, networks and organisations, were already in place. This is a typical example of hybridisation as described by Geels (2002).

\section{Biomass gasification $^{1}$}

The main driving force within the biomass gasification innovation system was the search for alternative energy technologies to replace fossil fuels. As a result, several research programmes (function

Table 2. Overview of co-firing activities in the Netherlands

\begin{tabular}{|c|c|c|c|c|c|}
\hline Year & Plant & Co-firing concept & $\begin{array}{l}\text { Total capacity } \\
\text { (MWe) }\end{array}$ & $\begin{array}{l}\text { Electricity } \\
\text { production } \\
\text { (GWh) }\end{array}$ & $\begin{array}{l}\text { Fuel (estimated amount co-fired in } \\
2004 \text { (kton) and type) }\end{array}$ \\
\hline 1996 & $\begin{array}{l}\text { Gelderland-13 (EPON -> } \\
\text { Electrabel) }\end{array}$ & Direct & 600 & 19.6 & $\begin{array}{c}4 \\
\text { Demolition wood }+ \text { olive seeds }\end{array}$ \\
\hline 1998 & $\begin{array}{l}\text { Maasvlakte } 1+2(\mathrm{EZH}-> \\
\text { E.ON) }\end{array}$ & Direct & $2 \times 518$ & 320 & $\begin{array}{l}230 \\
\text { Biomass pallets, animal waste (bone } \\
\text { meal) }\end{array}$ \\
\hline 1998 & $\begin{array}{l}\text { Amer-8 } \\
\text { (EPZ/PNEM -> Essent) }\end{array}$ & Indirect & 645 & 343 & $\begin{array}{c}320 \\
\text { Paper sludge, food industry waste }\end{array}$ \\
\hline 1999 & Borssele-12 (Essent) & Direct & 403 & 187.6 & $\begin{array}{c}108 \\
\text { Various organic sources }\end{array}$ \\
\hline 2001 & Buggenum-7 (Nuon) ${ }^{1}$ & Direct & 253 & 6.8 & Various organic sources \\
\hline 2002 & $\begin{array}{l}\text { Claus power plant } \\
\text { (Essent) }{ }^{2}\end{array}$ & Direct & $2 \times 640$ & 261 & Vegetable oil \\
\hline 2002 & $\begin{array}{l}\text { Harculo } \\
\text { (Electrabel) }\end{array}$ & Unknown & 350 & 47.4 & Bio-oil, cereals \\
\hline Total & & & & $1,131.2$ & \\
\hline
\end{tabular}

Source: based on Jünginger and Faaij (2005); Raven (2005)

Notes: 1. Coal gasifier

2. Natural gas plant 
knowledge development) were set up to assess the application of gasification technology for energy production, in which experimentation and research came up with positive results. The expectations of the experts grew as biomass gasification was increasingly talked about as the solution for sustainable energy production (function guidance of the search). This sequence of events corresponded with a positive interaction between the system functions: the more research that was carried out (function knowledge development), the more positive results were obtained and published (function knowledge diffusion) and the more resources were allocated to the technology (function resource mobilisation), ensuring the further development of biomass gasification (function knowledge development). This, in turn, stimulated entrepreneurs to take their chances and set up two large-scale plants for biomass gasification (function entrepreneurial activity) (see Table 3).

Thus, between 1992 and 1998, the system functions mentioned above interacted and the build-up of a virtuous cycle commenced that was strongly dominated by science and high technological expectations (function guidance of the search).

In the same period other actors in the biomass gasification innovation system expressed their disappointment that the national government had not provided uniform, consistent, and long-term regulations over the years (lack of function guidance of the search). In this respect the technology itself was perceived as positive, but the innovation system was criticised heavily. In addition, some actors were sceptical about the hype around biomass gasification technology; they warned entrepreneurs not to be carried away without first proving the technology. Furthermore, there was discussion about the lack of resources and the lack of support from advocacy coalitions.

Nonetheless, because of the hype and high expectations that dominated that period it seemed that these negative or lacking system functions were outweighed by the positive build-up of activities.

However, the energy market was liberalised in 1998 and the high expectations were quickly shattered (lack of function guidance of the search). Unsolved technical problems and poor economic performance prevented the introduction of biomass gasification into a turbulent market environment. This resulted in the discontinuation of the NorthHolland project and several small-scale plants that had been set up in previous years (lack of function entrepreneurial activity). In addition, most of the other activities in the innovation system were also discontinued; entrepreneurs and energy companies were reluctant to take high risks within the context of a liberalised market $(-\mathrm{F} 1)$. No more research and studies were carried out (no function knowledge development) and the allocation of resources (lack of function resource mobilisation) and specific guidance for biomass gasification was discontinued (lack of function guidance of the search). Additionally stricter emission regulations were introduced in 2000 , which resulted in the shutdown of several small-scale plants. Thus, the sequence of events after 1998 resulted in the collapse of the previous virtuous cycle due to technical problems and lack of guidance and market formation.

While the revival of biofuels seemed to bring biomass gasification technology back on the political agenda as a key technology for secondgeneration fuels (function guidance of the search), no increase was seen in other activities. The critics of the innovation system remained highly negative because inconsistent government policy was unable to realise a breakthrough for the 2G biofuels (lack of function guidance of the search).

The main blocking mechanism was the lack of guidance by the government to provide clear and consistent policies (lack of function guidance of the search) and the lack of a market niche (lack of function market formation) in which the entrepreneurs could have experimented and built up experience with the technology. At the beginning, the experts expected that biomass gasification would be the solution but because of the unsolved technical problems and inconsistent guidance by the government (lack of function guidance of the search) the opinions changed drastically as the energy market was liberalised. Liberalisation came too early for gasification as it was still an unreliable and expensive technology. Besides the unfortunate timing of the liberalisation, there was no additional time and space allowed for trial and error to solve the technical problems, resulting in investors and government considering the technology unfit for and unworthy of

Table 3. Overview of biomass gasification plants

\begin{tabular}{|c|c|c|c|c|c|c|}
\hline Year & Plant & $\begin{array}{l}\text { Gasification } \\
\text { concept }\end{array}$ & $\begin{array}{l}\text { Total capacity } \\
\text { (MWe) }\end{array}$ & $\begin{array}{c}\text { Electricity } \\
\text { production (GWh) }\end{array}$ & $\begin{array}{l}\text { Fuel (estimated } \\
\text { amount co-fired in } \\
2004 \text { (kton)) }\end{array}$ & Status of plants \\
\hline 1993-1998 & $\begin{array}{l}\text { Northern Holland } \\
\text { UNA }\end{array}$ & BIGCC with CFB & $20-30 \mathrm{MW}$ & - & - & $\begin{array}{l}\text { Terminated in } \\
\text { planning stage }\end{array}$ \\
\hline $\begin{array}{l}\text { 1995-1996; } \\
\text { 1997-2000 }\end{array}$ & $\begin{array}{l}\text { Amer plant, } \\
\text { Geertruidenberg } \\
\text { Essent }\end{array}$ & $\begin{array}{l}\text { Co-firing with } \\
\text { gasification }\end{array}$ & $\begin{array}{l}\text {-30 MW, } \\
83 \mathrm{MWth}^{1}\end{array}$ & n.a. & $\begin{array}{l}150 \text { kton } \\
\text { construction and } \\
\text { demolition wood }\end{array}$ & In operation \\
\hline
\end{tabular}

Note: 1. Loo and Koppejan (2002) 
further support (lack of function advocacy coalition). This led to the collapse of the biomass gasification innovation system.

\section{Stand-alone biomass combustion ${ }^{2}$}

In the early 1990s the energy sector agreed to contribute to the reduction of $\mathrm{CO}_{2}$ emissions and several technical options were explored, such as co-firing, gasification and stand-alone combustion. In 1995 the Third White Paper on Energy was introduced, which gave an impulse to energy companies such as Essent and Nuon to start up two stand-alone combustion projects (Cuijk and Lelystad respectively) (function entrepreneurial activity) (Kuiper, 1999; Novem, 2003; Jünginger and Faaij, 2005).

A ban on dumping combustible waste (function guidance of the search) that was introduced also triggered wood industries to rethink their options, and two wood companies installed combustion plants to process their surplus wood and produce electricity and heat for their own use (see Table 4 for an overview of stand-alone combustion plants). Furthermore, a tax exemption scheme 'Regulating Energy Tax' (REB) and a subsidy programme ' $\mathrm{CO}_{2}$ reduction plan' (function market formation, function resource mobilisation) provided favourable remuneration rates and subsidies for stand-alone biomass combustion projects (E\&MSpectrum, 1996; EnergieNed, 2000; Jünginger and Faaij, 2005).

Thus the trigger for stand-alone combustion plants came from the guidance of the government to increase the production of renewable energy (function guidance of the search), the ban on dumping combustible wood and favourable financial conditions (function resource mobilisation) that provided a niche market (function market formation) and resources for projects to be set up (function entrepreneurial activities). Research was carried out to compare the technology options and stand-alone biomass combustion won over biomass gasification (function knowledge development), because it was more reliable and with some technical improvements could be just as efficient. The expectations were high (function guidance of the search) and the above-mentioned projects were set up shortly thereafter.

However, in 2000 the Ministry of the Environment introduced stricter emission rules for biomass energy plants (lack of function guidance of the search) (DE, 2000; Stromen, 2000b). The Ministry hoped that with stricter emission rules the processing of waste wood would be promoted in large-scale biomass plants since they produced lower $\mathrm{NO}_{\mathrm{x}}$ emissions and had a higher energy efficiency than smallscale plants (Stromen, 2000b). In this respect the government expressed a clear preference for largescale plants, antagonising small-scale plants (negative function guidance of the search). In order for small-scale plants to comply with this regulation they had to add additional gas-cleaning units, which resulted in high additional costs for future smallscale plants up to $7 \mathrm{MW}$. This showed that the government was trying to select a technological option in an early phase of development, instead of waiting for the options to develop first. This resulted in several initiatives being stopped due to the uncertain availability of resources (lack of function resource mobilisation) and strict emission rules (lack of function guidance of the search). Projects that were only based on heat production were too expensive without subsidy, and the strict emission rules led to high costs due to additional cleaning steps for small-scale combustion plants that used waste wood (Kwant and Knoef, 2004).

Also, since the introduction of the REB, large quantities of renewable energy were being imported instead of being produced in the Netherlands, resulting in no more stand-alone plants being constructed. However, the flaw in the system was expected to be mended with the introduction of a new feed-in tariff system, 'MEP' (function market formation). Expectations about the implementation of the MEP were high (function guidance of the search), since a boost for renewable energy technologies was expected. However, the disappointment and indignation was

Table 4. Overview of stand-alone biomass combustion plants in the Netherlands in 2004

\begin{tabular}{|c|c|c|c|c|c|}
\hline Year & Plant & Combustion concept & $\begin{array}{c}\text { Biomass capacity } \\
\text { (MWe/year) }\end{array}$ & $\begin{array}{l}\text { Electricity production } \\
\text { (GWh) }\end{array}$ & $\begin{array}{l}\text { Fuel (estimated amount } \\
\text { co-fired in } 2004 \text { (kton)) }\end{array}$ \\
\hline 1995 & $\begin{array}{l}\text { De Lier } \\
\text { De Lange }\end{array}$ & CHP-installation of $3 \mathrm{MW}$ & 0.75 (in 1999) & n.a. & $\begin{array}{l}\quad 6 \text { (in 2002) } \\
\text { Sawdust, } \\
\text { wood-fibre }\end{array}$ \\
\hline 1996 & SchijndelHIS & $\begin{array}{l}\text { Grate firing with a steam } \\
\text { cycle }\end{array}$ & 1.2 (in 1997) & n.a & $\begin{array}{l}7 \text { (in 2002) } \\
\text { Clean wood }\end{array}$ \\
\hline 1996 & $\begin{array}{l}\text { Lelystad } \\
\text { Nuon }\end{array}$ & $\begin{array}{l}\text { Grate burner and steam } \\
\text { turbine }\end{array}$ & 1.3 (in 2001) & 47 & $\begin{array}{l}\qquad 4 \text { (in 2002) } \\
\text { Forestry thinnings and } \\
\text { residues }\end{array}$ \\
\hline 1997 & $\begin{array}{l}\text { Cuijk } \\
\text { Essent }\end{array}$ & $\begin{array}{l}\text { Bubbling fluidised bed } \\
\text { boiler }\end{array}$ & 25 (in 1999) & 150 & $\begin{array}{l}240 \text { (in 2004) } \\
\text { Clean wood chips }\end{array}$ \\
\hline Total & & & & 197 & \\
\hline
\end{tabular}

Source: Kuiper (1999); Novem (2003); Jünginger and Faaij (2005) 
correspondingly high when the introduction was delayed and the period of validity became shorter than originally requested (lack of function guidance of the search). The delay not only had effects on future projects, but also on current plants that continued to be unprofitable as long as the introduction of the MEP was delayed (DE, 2003a,b).

However, after several requests had been made by the bio-energy platform, Essent, and experts in the field (function advocacy coalition), the Ministry of Economic Affairs agreed with a remuneration period of 10 years, and as soon as the rates were implemented an impulse occurred in the biomass sector (function entrepreneurial activity) (see Table 5 for new projects) (DE, 2003c).

Nevertheless, just a couple of years later a deficit resulted in the budget and newly built plants and large bioenergy projects were not to receive any more feed-in tariffs between 2005 and 2007 in the hope of resolving the deficit (lack of function market formation) (Jünginger and Faaij, 2005). Because the deficit was still present in 2006 the feed-in tariffs were stopped completely, which meant that new biomass projects were not entitled to receive any tariffs (lack of function market formation). This action created a great deal of commotion and disappointment in the biomass sector and the entrepreneurs that had recently set up projects feared that they would have to be discontinued.

To summarise, in the beginning of this trajectory, lobby activities of the platform and the sector (function advocacy coalition) were successful in realising a change in institutional conditions (function guidance of the search) and the formation of a market (function market formation). This resulted in several entrepreneurial activities being started up (function entrepreneurial activity). However, as soon as the feed-in tariffs were removed (lack of function guidance of the search) all activities were stopped (lack of function entrepreneurial activity), given that the projects thus became unprofitable (lack of function market formation). This showed that system functions such as guidance and market formation were like 'on and off' switches that determined whether the evolution of stand-alone biomass combustion continued or stopped.

\section{Functional patterns}

The evolution of all three technologies was triggered by the need of the Dutch Government to comply with the targets to reduce $\mathrm{CO}_{2}$ emissions and produce renewable energy. The guidance provided by the government led to a build-up of system functions; however, as the institutional conditions were changed (i.e. liberalisation of the energy market) the three technology trajectories diverged from each other.

The institutional change had the least effect on biomass co-firing since the TIS was already in place and very few technological problems were present. Given that a niche market had been formed for co-firing by the electricity companies, which was subsequently maintained throughout the liberalisation process, the further development and diffusion of co-firing was ensured and eventually large-scale co-firing was implemented. In this case the necessary components - such as continuous policy, a shared long-term vision, the right conditions that facilitated actors to play their role in an efficient and effective way, and the capabilities of these actors to take part in transition process were in place.

Liberalisation of the market had the highest impact for the biomass gasification innovation system as that system was still fragile and had not built up enough momentum to counteract and withstand such a change. In this case it was especially the lack of a niche market, in which time and space were available for trial and error to solve the technical problems and improve profitability, that was the reason for failure. This clearly shows the nonlinearity of the innovation process of emerging technologies because engineers and researchers have to go back to the drawing table to solve technical problems. However, if there is no further guidance and support for the second trial, and the expectations are that the market will do the rest, than rejection of the emerging technology is the logical consequence as it is not competitive with the system already in place. The collapse of the gasification innovation system was due to the lack of continuous policy and shared long-term vision,

Table 5. Overview of stand-alone biomass combustion plants in the Netherlands, 2001-2005

\begin{tabular}{|c|c|c|c|c|c|}
\hline Year & Plant & Combustion concept & $\begin{array}{l}\text { Biomass capacity } \\
\text { (MWe/year) }\end{array}$ & $\begin{array}{l}\text { Estimated electricity } \\
\text { production } \\
(100 \% \text { capacity, GWh) }\end{array}$ & $\begin{array}{l}\text { Fuel (estimated amount } \\
\text { in kton) }\end{array}$ \\
\hline 2001 & $\begin{array}{l}\text { Goor } \\
\text { Cogas }\end{array}$ & Grate firing & 1.7 (in 2006) & 14 & Waste wood 17 \\
\hline 2004 & $\begin{array}{l}\text { Hengelo } \\
\text { BEC }\end{array}$ & Grate firing & 15 (in 2006) & 131.4 & Waste wood \\
\hline 2005 & Sittard BES & Bubbling bed & 1.2 (in 2005) & 10.5 & $\begin{array}{l}140 \text { (in 2008) } \\
\text { Organic, woody waste }\end{array}$ \\
\hline Total & & & & 156.8 & \\
\hline
\end{tabular}


unfavourable conditions where actors could not play their role in an efficient and effective way, and the lack of the necessary capabilities to take part in this transition process.

In the case of biomass combustion, entrepreneurs did not quite manage to switch to large-scale diffusion. While the system had been set up by the actors to such an extent that it was ready to be implemented, the liberalisation caused a delay because no niche market was created. Only after the MEP subsidy had been introduced did a market for green electricity start to form (function market formation), thus stimulating entrepreneurs to set up plants (function entrepreneurial activity). However, the moment the MEP subsidy was removed a few years later, the market collapsed (lack of function market formation) and no more entrepreneurial activity was forthcoming (lack of function entrepreneurial activity). This clearly showed that the formation or destruction of a market functioned as an 'on and off' switch for the implementation or rejection of stand-alone biomass combustion technology.

Activities undertaken within an innovation system must obtain enough momentum to overcome the early and fragile build-up period. The lack of one or more system functions, or a change in the institutional setting, can easily lead to the collapse of the innovation system. Similar to the biomass gasification case, several system failures - such as lack of continuous policy, no shared long-term vision, unfavourable conditions that obstruct actors from playing their role in an efficient and effective manner, and finally insufficient capabilities to take part in the transition process - also resulted in this system failing to move on to large-scale diffusion.

This shows that the dynamics of innovation systems are complex and that there is certainly no single, ideal development. However, this does not mean that the development and diffusion of emerging biomass technology cannot be steered or accelerated. In the next section we propose a new policy and a set of policy instruments that help to steer and accelerate the complex dynamics of innovation systems in order to successfully implement renewable energy technologies.

\section{The dynamics of innovation systems} are complex and there is certainly no single, ideal development; this does not mean that the development and diffusion of emerging biomass technology cannot be steered or accelerated

\section{Implications for policy-making}

\section{Major system failures}

In the analysis of the three cases a multitude of system failures came to the fore. In this section we will focus on three major failures. First, from all three cases it is clear that government policy lacks continuity and is not based on an explicit, broadly shared and long-term vision. A major consequence of this failure is that actors in the system feel uncertain whether financial conditions are guaranteed also in the long run and about where developments are heading as a shared long-term vision is absent. A second consequence of this system failure is that there is no actor in the system that can or will take the lead in the orchestration (initiation, facilitation, monitoring) of the development of the new TIS. Due to this lack, no necessary structural changes are implemented, coordination is weak and incumbent actors have excellent opportunities to resist the (often uncoordinated and weak) lobby efforts by the new entrepreneurs to change the system.

The next major system failure relates to the conditions necessary to facilitate actors to play their role in an effective and efficient way. An adequate infrastructure for tailor-made strategic intelligence and platforms for learning and experimenting are lacking and - as already said - guarantees for necessary long-term financial support are absent. As a result too few Neue Kombinationen are generated and niche markets formed - essential to prepare these innovations for their entrance on the real market and those that are, are not supported.

The last major system failure relates to the capabilities of the actors (also government) to take part in these transition processes. Government does not have the expertise and competence to develop policies that intervene in the development of the system in an orchestrated way and finds it difficult to manage the high, but often not too realistic, expectations. From the analysis of the cases it becomes clear that unrealistic expectations often result in deep disappointment and de-motivation, hindering the further development of the new TIS. Furthermore, actors, and government included, find it difficult to develop durable relations with other actors in the system, to articulate their demand and develop visions, strategies and action plans that are well linked up with the foreseen transition.

\section{Building blocks of a systemic policy}

In the following we will present first ideas on the building blocks of a more systemic policy aiming to support the development of the new TIS (and by this break down parts of the old TIS). First, however, we want to stress that these building blocks will not make much sense if government does not accept two essential starting points: government should be willing to guarantee the necessary continuity in policy 
and to take a major role in the orchestration of the developing system. Structural changes in innovation systems ask for stamina and endurance. Short-term actions only cause confusion and distortion of ongoing processes. This role does not imply that government should take the lead in pointing the direction of the development of the system.

The role of government should be more like the role of the Japanese Ministry for International Trade and Industry (MITI): identifying societal challenges, taking the lead in bringing relevant actors together, stimulating and facilitating their strategic dialogue and acting on the basis of the results of this dialogue. The UK, Finland and Taiwan are countries that have already accepted this long-term responsibility. They started programmes in important sectors of society with the aim to develop long-term strategies and took their responsibility in implementing the necessary changes in the (often sectoral) innovation systems that resulted from these strategies.

The Dutch Energy Transition Platform is a good first step in the development of such an approach in the Dutch energy sector. These examples show that even in short-term-oriented political systems, longterm policies are not impossible.

Starting point: defining the problem The first step in initiating a long-term transition focuses on the exploration of the problem.

- What precisely is the problem? Which technologies could contribute to solving this problem? What is the 'state of the art' of these technologies?

- Who is involved?

- What does the decision-space look like? and lastly,

- What information do the various actors need in order to develop their visions, strategies and plans?

In this phase a start-document answering these questions should be written by an 'as independent as possible' consortium of research organisations. If necessary, input from abroad should be mobilised to avoid a too parochial perspective.

Thinking: creating visions and generating ideas The next step is to build a network of relevant actors and facilitate them in developing visions, strategies and concrete plans. The UK Foresight approach developed in the 1990s could act as an inspiring example. The output of this phase is a broadly shared vision and suggestions for concrete plans and necessary changes in the innovation system to further develop these plans and turn them into a success.

Selecting: independent assessment of ideas and plans Based on the developed vision an independent organisation selects a limited number of promising plans and identifies the changes in the innovation system necessary to facilitate the further development of these plans. In this context, the experiences of organisations such as the Technology Rating International initiative, which provides an assessment of innovative plans based on a combined assessment of technical, market and 'management capabilities', could be helpful.

Executing: creating niches and conditions Having selected a limited number of plans and knowing the conditions that should be in place to realise them, the next step consists of three activities:

- Government should take care that the identified conditions are created. This may imply the removal of system failures, financing of new $R \& D$ programmes and/or the introduction of new regulations. The most important activity in this phase consists of financing and facilitating niche experiments. Facilitation includes the development of a strategic intelligence infrastructure. Because actors are the only persons who can identify the relevant information needs but in the beginning hardly have a complete and/or articulated overview of their needs, an interactive process is needed to feed them during the processes with tailor-made information, meeting the needs emerging during the further development of their plans (e.g. (Smits et al, 1995).

- Actors involved in the selected plans have to develop their plans further and experiment with them in a protected environment (niche experiment) in which sufficient resources and time is provided to be able to submit these plans to realistic tests.

- To avoid a decrease of innovativeness and prevent government from investing too much in the development of these plans, an independent unit (might be the same as the one involved in the selection procedure) will have to monitor the development of these plans. The major goal of this monitoring process is to avoid unwanted lock-in and the provision of timely warnings that private actors are able to take over (part of the financing) of government. Shaping the financing scheme as a revolving fund in which successful plans reimburse part of their revenues could also be considered. Furthermore, these monitoring results may result in feedback to the earlier stages of the development process or even to foregoing phases. For instance, it is possible that plans under development could be stopped and that - based on the gained insights - new plans could be selected.

To conclude, the proposed policy clearly can be characterised as a systemic policy. The policy development process starts with the development of a vision affecting actors, relations and institutions in the system. Realising such a vision demands involvement of a heterogeneous set of actors, the realisation of specific conditions, and long-term 
commitment. By this an orchestrated effort is made to introduce structural changes in the existing innovation system in order to facilitate the further development and implementation of emerging technologies that aim to serve a societal goal better than the existing technologies are able to. This type of policy is a great challenge for the policy-making system. However, when taking the systemic perspective seriously we only can conclude that reinforcing and/or altering innovation systems without any doubt asks for stamina and endurance.

\section{Acknowledgments}

The authors would like to thank Dr Andre Faaij for his comments on previous versions and two anonymous reviewers for the extensive and useful comments from which the paper benefitted a lot. They would also like to thank Dr Richard van den Broek and Dr Martin Jünginger for their time and empirical information. Finally, they would like to thank the Knowledge Network for System Innovations and Transitions and the Netherlands Organization for Scientific Research for their financial support.

\section{Notes}

1. Based on Negro et al (2008) where the empirical part and methodology are more elaborated but the underlying drivers and barriers are the same.

2. The narrative of stand-alone biomass combustion is based on Chapter 8 of Negro's PhD thesis (2007); the empirical description and analysis is the same.

\section{References}

Arnold, E 2007 Governing the Knowledge in an Innovation Systems World. UK: Technopolis.

Bergek, A 2002 Shaping and Exploiting Technological Opportunities: the Case of Renewable Energy Technology in Sweden. Sweden: Department of Industrial Dynamics.

Bijker, W, T Hughes et al 1987 The Social Construction of Technological Systems: New Directions in the Sociology and History of Technology. Cambridge, MA: MIT Press.

Borrás, S 2004 Analytical framework system of innovation theory and the European Union. Science and Public Policy, 31(6), December, 425-433.

Breschi, S and F Malerba 1997. Sectoral innovation systems: technological regimes, Schumpeterian dynamics, and spatial boundaries. In Systems of Innovation: Technologies, Institutions and Organizations, ed. C Edquist, ch. 6, pp. 130-156. London: Pinter.

Carlsson, B 1997. Technological Systems and Industrial Dynamics. Cleveland: Kluwer.

Carlsson, B and R Stankiewicz 1991 On the nature, function and composition of technological systems. Journal of Evolutionary Economics, 1, 93-118.

Davids, J A G 1984 Energie uit biologische systemen: 123-139.

DE 1989b Joule. Duurzame Energie, 19 November.

DE 1990 1990-EWAB programme. Duurzame Energie, 35.

DE 1991a Studie naar biomassa van eigen bodem. Duurzame Energie, 8 July.

DE 1991b Olifantsgras: siergewas wordt grondstof. Duurzame Energie, July.

DE 1992a Afval als belangrijkste duurzame energiebron. Duurzame Energie, 35, November.

DE 1992b Centrales en afvalhout. Duurzame Energie, 1992.

DE 1992c Electriciteit uit biomassa binnen handbereik. Duurzame Energie, 21 November.

DE 1992d EWAB programma. Duurzame Energie, 35, November.
DE 1992e Grotere rol bio-energie. Duurzame Energie, 20 November.

DE 1995 Hout als nevenbrandstof in kolencentrale. Duurzame Energie, 33, April.

DE 1996 EZH streeft naar 40\% bijstook. Duurzame Energie, 6, 22.

DE 1997 Kolencentrale Maasvlakte bijgestookt met biokorrels. Duurzame Energie, 16 August.

DE 1998 Checklist energie uit afval en biomassa. Duurzame Energie, 22 August.

DE 2000 Kleinschalige biomassacentrales krijgen wind tegen. Duurzame Energie, 38.

DE 2003a Energiesector heeft genoeg van gehannes en gejojo met cijfers. Duurzame Energie, 36.

DE 2003b Essent woedend over uitstel MEP. Duurzame Energie, 35.

DE 2003c Stel tarieven MEP ten minste drie jaar van te voren vast. Duurzame Energie, 41.

Dosi, G, C Freeman et al 1988 Technical Change and Economic Theory. London: Pinter.

E\&MSpectrum 1992 Tienjaarprogramma Afval 1992-2002. E\&MSpectrum, 16 April.

E\&MSpectrum 1996 Eerste warmte/kracht-installatie op hout in Schijndel. E\&MSpectrum, 5, 6 .

ECN 1994 Het Tweede Milieu Actieplan. Eerste hoofdstuk 'Focus' in het Energie Verslag: Nederland.

ECN 2002 Kolenconvenant getekend. Energie Verslag Nederland 1993-2005. The Netherlands.

ECN Report; R K R van Ree and T de Lange 2000 Biomass Cofiring Potential and Experiences in the Netherlands. Petten, Energy Research Centre of the Netherlands, Biomass Department.

Edquist, C 1997 Systems of Innovation; Technologies, Institutions and Organisations. London: Pinter.

Edquist, C 2001 The Systems of Innovation Approach and Innovation Policy: an Account of the State of the Art. Aalborg: DRUID.

Edquist, C 2004 Reflections on the systems of innovation approach. Science and Public Policy ${ }_{2}$ 31(6), December, $485-489$.

EnergieConsulent 1992a Optimalisatie van de electriciteitsopwekking bij afvalverbranding. EnergieConsulent, 4 April.

EnergieConsulent 1992b Richtlijn Verbranden 1989. EnergieConsulent, 4, April, 4-8.

EnergieNed 2000 MAP Eindrapportage 1990-2000. The Netherlands: EnergieNed.

Etzkowitz, $\mathrm{H}$ and L Leydesdorff 2000 The dynamics of innovation: from national systems and 'mode 2' to Triple Helix of university-industry-government relations. Research Policy, 29, 109-123.

EU 1990 Thermie: Non-nuclear Energy Programme 1990-1994. <http://ec.europa.eu/research/joule/joule3.html>, last accessed 20 May 2006.

EZ, Ministry of Economic Affairs 1993 Vervolgnota (Sequel of White Paper).

Faaij, A, R van Ree et al 1997 Gasification of biomass wastes and residues for electricity production. Biomass and Bioenergy, 12(6), 387-407.

Freeman, C 1987 Technology Policy and Economic Performance: Lessons from Japan. London: Pinter.

Freeman, C 1997 The diversity of national research systems. In Science in Tomorrow's Europe, eds. R Barré, M Gibbons, J Maddox, B Martin and P Papon. Paris: Economica International.

Freeman, C and B A Lundvall 1988 Small Countries Facing the Technological Revolution. London and New York: Pinter.

Geels, F W 2002 Technological transitions as evolutionary reconfiguration processes: a multi-level perspective and a casestudy. Research Policy, 31(8-9), 1257-1274.

Hekkert, M P, R A A Suurs et al 2007 Functions of innovation systems: a new approach for analysing technological change. Technological Forecasting and Social Change, 74(4), May, 413-432.

IPO 2003 Interprovinciale rapportage 2003: Milieu, Water, Landbouw en Natuur. The Netherlands: IPO.

Jacobsson, S and A Bergek 2004 Transforming the energy sector: the evolution of technological systems in renewable energy technology. Industrial and Corporate Change ${ }_{\perp} 13(5)$, October, 815-849.

Jacobsson, S and A Johnson 2000 The diffusion of renewable energy technology: an analytical framework and key issues for research. Energy Policy, 28(9), 625-640. 
Joerg, G and P Larrue (2004). Policy Instruments for Sustainable Innovation. J-F van Giessel \& G van der Veen, Technopolis.

Johnson, A 1998 Functions in Innovation System Approaches. Sweden: Chalmers University of Technology.

Johnson, A and S Jacobsson 2000 Inducement and blocking mechanisms in the development of a new industry: the case of renewable energy technology in Sweden. In Technology and the Market: Demand, Users and Innovation, eds. R Coombs, $\mathrm{K}$ Green, A Richards and V Walsh, pp. 89-111. Cheltenham, Edward Elgar.

Johnson, A and S Jacobsson 2002 The emergence of a growth industry: a comparative analysis of the German, Dutch and Swedish wind turbine industries. In Transformation and Development: Schumpeterian Perspectives, eds. S Metcalf and U Cantner. Heidelberg: Physica/Springer.

Jünginger, M and A Faaij 2005 IEA Bioenergy task 40: Country report for the Netherlands, NWS.

Klein Woolthuis, R, M Lankhuizen et al 2005 A system failure framework for innovation policy design. Technovation, 25(6), 609-619.

Kuhlmann, S, P Boekholt et al 1999 Improving distributed intelligence in complex innovation systems. Karlsruhe: Fraunhofer ISI.

Kuiper, L 1999 IEA Bioenergy: Task 17: Status Report on Energy Crops in the Netherlands. September.

Kwant, $\mathrm{K}$ and $\mathrm{H}$ Knoef 2004 Status of gasification in countries participating in the IEA biomass gasification and GasNet activity. In IEA Bioenergy Task 33 Biomass Gasification and EU Gas net, eds. K Kwant and H Knoef, pp. 1-178. SenterNovem \& BTG.

Loo, V S and J Koppejan 2002 Handbook of Biomass Combustion and Co-firing. Twente University Press.

Lundvall, B-A 1992 Introduction. In National Systems of Innovation: Toward a Theory of Innovation and Interactive Learning, ed. B-A Lundvall, pp. 1-19. London: Pinter.

Morris, M, L Waldheim et al 2005 Status of Large-scale Biomass Gasification and Prospects.

NE\&S 1981 Voedsel of brandstof verbouwen? Nieuwsbrief Energie and Samenleving, 3 December.

NE\&S 1982 Energie en chemicalien uit bomen: nuttig en nodig. Nieuwsbrief Energie and Samenleving, 8 February.

NE\&S 1983 Energie uit biomassa: een overzicht. Nieuwsbrief Energie and Samenleving, 7 February.

Negro, S O 2007 Dynamics of technological innovation systems: the case of biomass energy. Innovation Studies.

Negro, S O, M P Hekkert et al 2007 Explaining the failure of the Dutch innovation system for biomass digestion: a functional analysis. Energy Policy, 35, 925-938.

Negro, S O, R A A Suurs et al 2008 The bumpy road of biomass gasification in the Netherlands: explaining the rise and fall of an emerging innovation system. Technological Forecasting and Social Change, 75(1), 57-77.

Nelson, R 1992 National systems of innovation: a retrospective on a study. Industrial and Corporate Change, 2, 347-374.

Nelson, R 1993 National Innovation Systems. New York: Oxford University Press.

Nelson, R R and S G Winter 1977 In search of a useful theory of innovation. Research Policy, 6(1), 36-76.

Novem 1984 Bio-energie van eigen bodem. Novem.

Novem 2003 Bio-energie van eigen bodem. Novem.

O'Doherty, D and E Arnold 2001 Understanding Innovation: the Need for a Systemic Approach. UK: InterTrade Ireland.

Raven, R 2005 Strategic niche management for biomass: a comparative study on the experimental introduction of bioenergy technologies in the Netherlands and Denmark. Sustainable Studies and Technology.

Rip, A 1978 Wetenschap als Mensenwerk. Over de Rol van Natuurwetenschappen in de Samenleving. Baarn: AMBO.

Sabatier, P A 1988 An advocacy coalition framework of policy change and the role of policy-oriented learning therein. Policy Sciences, 21(2-3), 129-168.

Sabatier, P A 1998 The advocacy coalition framework: revisions and relevance for Europe. Journal of European Public Policy, 5(1), 98-130.

Sabatier, P A and H C Jenkinssmith 1988 Policy change and policy oriented learning - exploring an advocacy coalition framework: introduction. Policy Sciences, 21(2-3), 123-127.

Saxenian, A 1991 The origins and dynamics of production networks in Silicon Valley. Research Policy, 20(5), October, 423-437.

Schot, J, R Hoogma et al 1994 Strategies for shifting technological systems: the case of automobile system. Futures, 26(10), 1060-1076.

Smits, R 2002 The new role of strategic intelligence. In Strategic Policy Intelligence: Current Trends, the State of Play and Perspectives, IPTS Technical Report Series, eds. A Tubke, K Ducatel, J Gavigan and P Moncada-Paternò-Castello. Seville: IPTS.

Smits, R and S Kuhlmann 2004 The rise of systemic instruments in innovation policy. International Journal of Foresight and Innovation Policy, 1(1), 1-26.

Smits, R, A Leyten et al 1995 Technology assessment and technology policy in Europe: new concepts, new goals, new infrastructures. Policy Sciences, 28, 272-299.

Stromen 2000a Akkoord over kolencentrales. Stromen, 2(11), 3 June.

Stromen 2000b NOx-eisen leidt to grotere biocentrales. Stromen, 2(10), 5 May.

Stromen 2001a Bijstook Nijmegen verboden. Stromen, 3(13), 13 July.

Stromen 2001b Biomassa als duurzame energie bron onder vuur. Stromen, 3(8/9), 13 June.

Stromen 2001c İmport biomassa word nog niet breed gedragen. Stromen, 3(12), 22 June.

Stromen 2001d Twee emissieregimes voor biomassa stromen. Stromen, 3(4), 2 March.

Suurs, R A A and M P Hekkert 2005 Naar een methode voor het evalueren van Transitietrajecten: Functies van innovatiesystemen toegepast op biobrandstoffen. Utrecht University: Innovation Studies, Copernicus Institute,.

Suurs, R A A and M P Hekkert (submitted) Patterns of cumulative causation in the formation of a technological innovation system: the case of biofuels in the Netherlands. Research Policy.

TweedeKamer 1974 Eerste Energie Nota. The Hague: Ministry of Economic Affairs.

TweedeKamer 1979 Nota Energiebeleid. Ministry of Economic Affairs.

TweedeKamer 1990 Energiebesparingsnota. Tweede Kamer der Staten-Generaal.

Vrom, M V 1987 Besluit emissie-eisen stookinstallatie milieubeheer $A$. The Netherlands: Ministry of Housing, Spatial Planning and the Environment.

Vrom, M V 1989 Nationaal Milieuplan (NMP). The Hague.

Williams, R H and E D Larson 1996 Biomass gasifier gas turbine power generating technology. Biomass and Bioenergy, 10(2-3), 149-166.

Ziman, J 2001 Real Science: What it is, and What it Means. Cambridge: Cambridge University Press. 